\title{
CHARACTERISATION OF TECHNOLOGICAL COLLABORATIONS AND EVOLUTION IN THE SPANISH DEFENCE INDUSTRY
}

\author{
Callado-Muñoz F.J. ${ }^{a}$, Fernández-Olmos M. ${ }^{\text {, }}$ Ramírez-Alesón, M. ${ }^{\mathrm{b}}$ and Utrero-González \\ $\mathrm{N}^{\mathrm{a}}$ \\ ${ }^{a}$ Corresponding author. Defence University Centre, Zaragoza, Spain. \\ ${ }^{b}$ Department of Management and Business Organization, University of Zaragoza, Spain.
}

Francisco José Callado Muñoz https://orcid.org/0000-0003-1399-5484

fcallado@unizar.es

Associate Professor

Defence University Centre

Academia General Militar

Ctra. De Huesca s/n, 50090

Zaragoza (Spain)

Marta Fernández Olmos https://orcid.org/0000-0002-5623-2391

maferno@unizar.es

Associate Professor

Faculty of Business and Economics

C/ Gran Via 2

University of Zaragoza

Zaragoza 50005

Marisa Ramírez Alesón https://orcid.org/0000-0002-9758-0149

mramirez@unizar.es

Full Professor

Faculty of Business and Economics

University of Zaragoza

C/ Gran Via 2

Zaragoza 50005

Natalia Utrero González https://orcid.org/0000-0001-9304-3517

n.utrero@unizar.es

Associate Professor

Defence University Centre

Academia General Militar

Ctra. De Huesca s/n, 50090

Zaragoza (Spain)

\begin{abstract}
Collaboration with technological partners as an innovation strategy has become widespread in recent years, and all sectors are immersed in this process. In particular, the defence industry is characterised by the technological complexity of the products and services offered, together with a constant innovation process. However, data that allow us to identify characteristics that are found in collaboration contracts are not usually available in this sector. This could explain the scarcity of research on collaborations in the defence industry. This paper addresses this gap in the literature by studying the different characteristics of both the technological partners and the development agreements over a long period that covers pre-crisis, crisis and post-crisis years. This is possible thanks to a database of more than 300 collaboration technology agreements between public and private organisations and the Spanish Ministry of Defence from 19992017. Three cluster analyses are used to identify different typologies of technological collaborations. The results provide the Ministry of Defence with a clear picture of the type of collaborations in the Defence industry, their partners and their behaviour under
\end{abstract}


different economic conditions, which will help it identify the type of collaborations that can contribute to improving the design of its innovation strategy.

\section{Keywords:}

Technological collaborations, Spanish Ministry of Defence, cluster analysis

\section{INTRODUCTION}

The simple but powerful idea that technological collaborations are important for the innovation performance of firms is by no means a completely new phenomenon. However, in recent years, the increasing speed of technological change, the greater complexity of technological advances and the growing investments required are driving firms to carry out technological collaborations in order to maintain their innovation capacity for long-term success. This is especially relevant in industries such as the automobile sector (Badillo, Llorente, Moreno 2017), biotechnology (Baum, Calabrese, and Silverman 2000), pharmaceutical (Li, Zheng, and Wang 2016), and defence (Mowery 2010), among others.

With respect to the defence sector, promoting technological collaborations (especially with emphasis on dual-use technology) has become essential to maintaining a strong defence technology industrial base and improving economic competitiveness (te Kulve and Smit 2003). However, although the literature on the defence industry is extensive (Dunne and Smith 2016), to the authors' knowledge, few studies analyse defence R\&D collaborations and contracts (see Outdot 2010 for an exception) and their evolution. Most previous papers that analyse defence $R \& D$ focus on US agencies such as DARPA, NASA or SBIR (see Fuchs 2010, Mazzucato, and Robinson 2018 and Audretsch, Link, and Scott 2002 respectively among others). At national level, apart from the analysis of the US (e.g. James 2004), studies on France (e.g. Bellais and Guichard 2006 and Belin et al. 2019), UK (e.g. Hayward 2005 and Hartley 2018), Norway (e.g. Berg, Ofstad, and Øhrn. 2019) and Spain (e.g. Duch-Brown, Fonfría, and Trujillo-Baute 2014 and García-Estevez and Trujillo-Baute 2014) can also be found.

Although related, our starting point is different. The main novelty of this paper is that we look directly at technological collaboration contracts and not at R\&D in general terms, to identify the most generally preferred type of collaboration and partners. Since innovation is the result of a collective endeavour, having more information and being able to analyse partners becomes important. Likewise, most of the previous studies on R\&D collaborations focus on the initial conditions or assume that they do not change, but it is 
known that technological collaborations evolve over time. Hence, we take into account the dynamics over time to fill this gap in the previous literature. Our general objective is then to investigate R\&D agreements and technological partners in contracts signed by the Spanish Ministry of Defence (MoD) mainly during the $21^{\text {st }}$ century. Specifically, our ultimate aims are to identify if there are different typologies of technological collaborations and subsequently different typologies of partners, and how they evolve over a period that covers pre-crisis, crisis and post-crisis years. Thus, we take a more indepth look at the defence industry and its collaborations.

In order to achieve our objectives, we have constructed a unique database of contracts and partners in technological collaborations with the Spanish MoD using information from three different official sources. Our final sample consists of more than 300 technological collaboration agreements between various public and private organisations (108 companies or institutions) and the Spanish MoD from 1999 to 2017.

Our findings contribute to enhancing the available knowledge of an industry as complex as the defence industry, as we offer a new, complete and very recent vision of the sector and its collaborations. Indeed, we have clearly identified three types of technological collaborations that have been adapted over time in this industry. This adaptation has taken place in parallel with the evolution of partners and as a response to the favourable or unfavourable economic conditions. These findings may therefore serve to design more efficient contracts and to promote collaborations with more suitable partners. Consequently, they can have profound research policy implications. Since most technological collaborations are affected by ambiguity and complexity, knowing the crucial elements of contracts (number of partners, duration, objective, nationality, among others), as we do in this paper, provides governments with valuable knowledge to identify effective policy instruments, which foster collaborations. Moreover, collaborations are not always spontaneous (Matt, Robin and Wolff 2012). Policy-makers should thus understand the required characteristics of the partners, and this would encourage them to choose the right collaborations. Other implications stem from two conspicuous trends. The first is the significant transformation of the defence sector due to the constant incorporation of new and more advanced technologies (Dunne and Smith 2016). The second is the increasing accountability of military R\&D expenditure. This is due to the large investments in military R\&D over total government R\&D expenditures in Spain, despite defence budget cuts (Schmid 2018), and the need for fiscal consolidation. In this scenario, accountability regarding public investments becomes more important and it is 
imperative for policy makers to offer an economic rationale for their support of public/private technology partnerships as well as to formulate and demonstrate means for evaluating such relationships. We must bear in mind that this evaluation is problematic, due to the long maturation time of these policies and the difficulty of assessing the achievement of goals within the increasing complex defence environment (Martí Sempere 2015). Thus, understanding the nature and evolution of defence technology contracts and partners seems crucial to discern and emulate efficient relationships and to improve collaboration management. Therefore, our results will help the $\mathrm{MoD}$ to analyse the specific configuration of contracts that would favour goal congruence, or that are more likely to increase innovation (Rihoux 2006), as well as facilitating the development of economic evaluation assessment and reform, should this be needed.

The rest of the paper is organised as follows. In the next section (2), we present the main theoretical background and describe the global and Spanish defence industry. The sample and variables used for the characterisation of the technological collaborations in the Spanish Defence industry are introduced in section 3, along with a brief description of the evolution of the sample. The empirical analyses and the identification of typologies of agreements and partners are discussed in section 4. Finally, the conclusions, implications, and future lines of research are set out in section 5.

\section{BACKGROUND: TECHNOLOGICAL COLLABORATIONS AND DEFENCE INDUSTRY}

There is a longstanding interest in the effects of technological collaborations, which are widely recognised as major drivers of innovation performance in firms, and are usually included in the innovation strategies. Technological collaborations involve agreements between firms, but also between firms and other organisations (Mowery and Sampat 2005). They can last from several months to a few years and often include user-driven innovation. Governments, in fact, can use strategic partnering as a mechanism to intensify technological processes and economic competitiveness in high-technology manufacturing and service sectors (Hagedorrn, Link and Vonortas 2000).

Hagedoorn, Link and Vonortas (2000) highlight that governments and policy authorities should be cautious since partnerships can hinder competition and encourage the creation of kinds of static and dynamic monopolies in existing or future markets. However, Mazzucato (2013) asserts the positive effects of state investment in innovations for economic development and growth. In particular, the role of these public-private 
technological collaborations would be more relevant in those economic fields characterised by high-risk $R \& D$ investments that cannot be borne entirely by private sectors (Mazzucato 2016). Areas such as defence, energy, transport and health have benefited from R\&D intensive procurement (Edler and Georghiou 2007). Accordingly, public-private research partnerships and mission-oriented collaborations are receiving increased attention (Brogaard 2017) for their role in the development of general-purpose technologies (Torregrosa-Hetland et al. 2019) and the Grand Societal Challenges' debate (Mowery 2012).

\subsection{Global Defence Industry}

National defence represents a significant share of most OECD governments' missionoriented R\&D spending (Mowery 2010). Since technological superiority is considered a key element in achieving defence effectiveness, defence R\&D addresses a highly specific purpose: equipping armed forces with up-to-date technology (Daffix and Jacquin 2009). In fact, $R \& D$ plays a major role in accessing relevant leading-edge technologies to achieve defence effectiveness (Bellais 2009). Furthermore, as the defence industry is producing not for an anonymous market but for a specific customer, it implies that innovation and R\&D investments have to be specially attuned (Smit, Elzen and Enserink 1998). Accordingly, ministries of defence develop collaborations with specialised defence business groups and/or scientists to develop their innovation ideas (Martí Sempere 2015). These peculiarities have made defence $R \& D$ different from other mission-oriented R\&D spending (Edler and Georghiou 2007). Moreover, as national defence-oriented $\mathrm{R} \& \mathrm{D}$ has been deeply concerned with achieving technological development to gain military superiority over potential enemies, civilian spillovers have never been significant goals of these programmes (Mowery 2012). In addition, little regard has been paid to economic feasibility, and limiting diffusion of results outside core participants has been encouraged (Soete and Arundel 1993). The "dual use technology concept” was introduced to provide an opportunity for the wider exploitation of research and manufacturing efforts beyond their initial (military or civilian) goals (Molas-Gallart 1997). This may entail important changes in the defence industry and in the way defence firms and laboratories actually operate. Accordingly, promoting networking and communication channels between the civilian and the defence sector, both within the firm or inter-industries, as well as introducing legal changes to allow exploitation of government property rights in products with a marked dual nature would be welcome steps toward a more intense cooperation (Martí Sempere 2018). 
Given that the defence sector is embedded in high technology industries, reducing the separation of the civil and military spheres for the better exploitation of R\&D resources can create positive synergies and ensure efficient diffusion of technological innovations to and from the military sphere (Bellais and Guichard 2006). In this sense, James, MolasGallart and Stankiewicz (2019) claim that the $21^{\text {st }}$ century defence technology procurement system is in transition due to the declining importance of defence markets and the rapid incorporation of critical civilian technologies. Indeed, technologies developed within civil projects are now "spinning-in" to the military sector, and defence firms are increasingly turning to civilian technology that can then be adapted for military applications. Therefore, to the extent that defence procurement relies more heavily on externally developed technologies, collaborations with industry will be even more necessary to gain access to and adapt these dual technologies to defence applications (Ham and Mowery 1998).

Meanwhile, a process of integration has taken place in Europe to develop a sustainable European market to achieve economies of a scale comparable to those already enjoyed by the major global competitors. Institutions such as the European Defence Agency (EDA) aim to coordinate the defence market and to harmonise competition within the European framework. In fact, the European Defence Fund (EDF), launched in 2017, introduces ways to support the complete capability development cycle, from research, through development, to acquisition. This means ensuring defence-specific skills in several technologically advanced areas for effective and efficient production that can ultimately help the competitiveness of European defence industry in international markets $^{1}$.

\subsection{Spanish Defence Industry}

The Spanish defence industry is composed of a set of heterogeneous companies that provide weapons, textiles, electronics and services (Duch-Brown, Fonfría and TrujilloBaute 2014). Traditionally, it is represented by a small number of large contractors and many small and medium-sized companies that are usually second-tier contractors (Álvarez and Fonfría 2000). In this respect, the MoD has endeavoured to develop a more cohesive industry. The objective is to promote and prepare small and medium enterprises (SMEs) through R\&D and productive investments to modernise the industry's production chains and thus increasing overall competitiveness (IDS 2017).

\footnotetext{
${ }^{1}$ https://ec.europa.eu/growth/sectors/defence/skills_en
} 
The sector has undergone significant changes, broadening its product range and incorporating new and more advanced technologies (García-Estevez and Trujillo-Baute 2014). At the same time, institutional support for internationalisation through government-to-government accords and the development of “defence diplomacy" (Arteaga 2013) has permitted the industry to be involved in cross-border programmes. All these efforts together have resulted in a major increase in its export capacity, placing the industry among the ten largest exporters (SIPRI 2020).

In order to encourage the sector to continue adapting to new circumstances, the MoD set an explicit defence industrial strategy ${ }^{2}$ (DIS) to promote coordination and cooperation with the Spanish defence industry. Moreover, in 2010 and then in 2015, the defence technology and innovation strategy (DTIS) was defined to help centralise the management and planning of $R \& D$ and prioritise strategic technological capabilities. Both DIS and DTIS show the efforts by the MoD in two related respects. First, to cope with the European defence initiatives that were launched in 2013 (at the December European Council) and then expanded in 2016 with the approval of the EU Global strategy, and the associated mechanisms to implement it. Second, to stimulate modernisation, to prioritise technologies and sectors (such as electronics) and to build a strong technological base to help the Spanish Armed Forces acquire the necessary capabilities to run their missions. Accordingly, significant technological activity would be needed to satisfy demand and might modify the civil economic activity composition through higher investment in sectors such as electronics and aerospace (Saal 2001). This is the so-called demand-pull mechanism (García-Estevez and Trujillo-Baute 2014). In this way, large national companies would be able to undertake and lead complex projects and be better prepared to participate in international programmes; SMEs, meanwhile, would gain in size and could be able to develop specialised niches ${ }^{3}$. In addition, with well-designed collaboration contracts, the MoD will not only facilitate the modernisation and prioritisation of technologies and sectors, but also direct its strategy to help in future evaluations and increase the commercialisation of results that allow not only the risks of innovation to be socialised but also the rewards (Mazzucato and Robinson 2018). This paper studies the nature and evolution of collaboration contracts as a first step in this direction.

\footnotetext{
${ }^{2}$ Approved for the first time in 2010.

${ }^{3}$ Ministry of Defence. Defence Innovation and Technological Strategy (2015).
} 


\section{SAMPLE, VARIABLES AND EVOLUTION}

In order to identify different patterns of technological contracting in the Defence industry, we start with 509 collaboration agreements signed by the Spanish MoD since 1999. The sample provides information about the name of the agreement, the year or years of the investment (start and end date), the total amount of investment and the object of the agreement ${ }^{4}$. From this initial information, we look for the company, or institution that signed the contract, as published in the Spanish Official State Gazette. We obtained the name of 344 partners. In order to characterise these partners, the information is completed mainly with the Iberian Balance Sheet Analysis System (SABI) database, which provided information for 108 organisations. Thus, our final and unique sample corresponds to 322 agreements with 108 partners and the Spanish MoD, from 1999 to 2017 (table 1). This period can be divided into three sub periods: pre-crisis, crisis and post-crisis, namely 1999-2007, 2008-2014 and 2015-2017 ${ }^{5}$. This division allows us to analyse technological collaborations in different economic contexts and budgetary conditions for the Spanish $\mathrm{MoD}^{6}$ and study the evolution of technological agreements and partners.

\section{INSERT TABLE 1}

The number of partners is smaller than the number of collaborations. Most of the partners (67\%) have collaborated only once throughout the period with the Spanish MoD. Conversely, more than $50 \%$ of the technological agreements were signed with a small group of organisations (8 firms). This concentration of agreements in a few partners may be related to the importance of trust in the development of defence innovation. The tailormade nature of defence innovation awards an agency nature to the contracts (Martí Sempere 2015). Trust may provide efficiency benefits through reduced search and monitoring costs as well as increased collaboration flexibility (Dyer and Chu 2003). Furthermore, it can be observed that the number of collaborations does not show a clear trend between periods. Indeed, 2005 with 47 agreements, 2011 with 40 and 2015 with 38 shows the years with the highest number of collaboration agreements for the whole period, and also for each sub period.

In order to characterise technological collaborations, we identify three groups of variables depending on the object, type and importance of the collaboration. They are briefly

\footnotetext{
${ }^{4}$ In some cases, part of this information is missing.

5 The economic crisis started in Spain in 2008; there was a slight recovery in 2011 but a second recession emerged in 2012 (Linde 2014).

${ }^{6}$ The budget of the Spanish MoD fell from 0.77 of the GDP in 2007 to 0.54 in 2014 (Pérez Munielo 2015, p.100)
} 
presented and justified in the following lines and the annex presents the measurement of each variable.

The Object of the Collaboration has been defined based on the classification used by the MoD (Ministerio de Defensa 2017). In particular, we identify eight dummy variables that reflect eight different types of objects: 1) Armament (e.g. missiles, weapons, ammunitions) 2) Electronic (e.g. circuits, connectors, optoelectronics), 3) Communication (e.g. radio, radar, satellite, sonar, detection systems) 4) Software (e.g. simulation programmes, computer programs, virtual reality) 5) Inputs (e.g. raw material and auxiliary industry), 6) Tech_support (services of technical support for different activities and products) 7) Vehicle (land, maritime and aircraft vehicles and platforms), and 8) Others (those not included in previous categories).

A second group of variables reflects the Type of Collaboration (four dummies), since the determinants and the consequences could be different depending on the type: vertical, institutional, consultancy and international. Vertical collaborations are more likely to have a better understanding of the needs and requirements of their clients or suppliers. In the case of defence collaboration, ministries of defence are the end client and they search for better equipment (mostly tailor-made) with limited resources.

Institutional collaborations pursue the combination of the know-how that firms and organisations have with expertise and knowledge from research institutes and universities. Traditionally, institutional collaborations in defence have been very important in the US, but appear to be less relevant in the other OECD countries (Mowery 2010 2012). The situation seems to be changing in the European Union with the H2020 EU Research and Innovation programme ${ }^{7}$ (European Commission 2018 and 2019). Consultancy collaborations reflect that MoD sometimes requires expert or professional advice on a particular research field, as it develops its activities in several, diverse areas. It is also common to differentiate between national and foreign partners. Collaborations with foreign partners (international collaborations) allow firms not only to gain access to new knowledge but also to facilitate entry into new markets (Ferreira et al. 2015). Although international cooperation has been scant in the past (Hayward 2005), the recent changes in the global and European defence markets seem to encourage international collaborations.

\footnotetext{
${ }^{7}$ H2020 EU Research and Innovation programme aims at facilitating public and private sectors to work together in delivering innovation and that acknowledges emerging technologies with dual use and new security challenges as relevant issues. https://ec.europa.eu/programmes/horizon2020/what-horizon-2020
} 
In order to account for the importance of the collaboration agreement, several variables are included based on the amount of total investment, duration of the agreement and monthly investment. The latter is included in order to construct a comparable variable to measure the importance of the amount invested.

In addition to the variables related to the contract, we analyse the main characteristic of the partners that the previous literature considers could influence the development and success of the collaboration (see Annex). The size and experience is a usual characteristic of the partner that could influence the development and success of the collaboration (Franco and Gussoni 2014). The most experienced companies tend to be the oldest firms and these are generally regarded as facing smaller financial barriers when engaged in technological collaborations (Aristei, Vecchi and Venturini 2016). Furthermore, we distinguish whether the partner is part of an industrial group or not and the location of its headquarter (from Spain or domestic, European Union and the rest of the world).

Finally, the technological activity of the organisation is included following previous literature that suggests that technology-intensive industries may offer different technological opportunities (Antolín-López et al. 2015) and thus may influence the success of technological collaborations. Based on the industry classification on R\&D intensities provided by the Organisation for Economic Cooperation and Development (OECD, 2011), we differentiate between high, medium and low-tech industries.

Table 2 presents the characteristics of collaborations and partners for each sub period and for the whole sample. It also includes the significant differences on the variables between sub periods by way of the Dunn-Bonferroni test ${ }^{8}$.

\section{INSERT TABLE 2}

As a first result, we observe differences in importance and tendency in most of the variables among sub periods. Regarding the object of the collaborations, collaborations related to technical support activities have acquired more relevance during the crisis period (2008-2014). Although not significant, the contrary has been the case for communications. In the post-crisis period (2015-17), the importance of electronics, communications, software and vehicles seems to increase. Therefore, it would indicate that the intermingling between civil and military technologies in Spain is increasing, as has been evidenced for the global defence market.

Although vertical collaborations are the most common agreements established in the

\footnotetext{
${ }^{8}$ Dunn test is a non-parametric pairwise multiple-comparison procedure with Bonferroni correction.
} 
Defence industry over the whole study period, the predominant role of consultancy occurs before the financial crisis (1999-2007). As expected, institutional agreements have gained a greater role during the crisis and have maintained this afterwards. This rise could be related to the growing contribution of institutional agents to economic recovery and the establishment of the EU H2020 security challenge research programme.

International collaborations have a significant presence in the first period (19\%). This evidence may relate to the presence of Spain in international defence organisations to develop new systems and platforms such as OCCAR. In any event, domestic partners are still the preferred option. This result suggests that Spain, like other European countries, although participating in international agreements, has traditionally aimed to protect its domestic defence industrial base for military-strategic reasons, such as security of supply, operational sovereignty and/or for economic reasons in terms of jobs, technology and balance of payments benefits (Hartley 2008).

As regards total investment, there is a negative trend over the period. The sharp fall in average total investment (a drop of 88 per cent) during the crisis did not recover in the post-crisis period. The same negative pattern is observed in the duration of contracts. However, the average duration of the contracts for the whole period (26.03 months) is similar to that of technological collaborations, boosted by the Spanish Centre for the Development of Industrial Technology (22.63 months), but it is not very long compared to other R\&D programmes in Europe (Montoro-Sanchez, Mora-Valentin and GuerrasMartín 2006).

Partners involved in technological agreements are, on average, large companies especially during the first sub-period. However, during the post-crisis period, it seems that much more attention has been paid to collaborating with small and medium firms (SMEs) as the median is 207 employees. This evidence is in line with the objectives of defence innovation and technological strategy to promote large companies to be able to undertake complex projects and participate in international programmes, on the one hand, and to reinforce small and medium-sized firms to develop specialised niches that can help industrial outcomes, on the other.

Taking into account that technological collaborations in the Defence industry generally require a long-term commitment, partners' experience increases over the period and becomes important because it is expected to provide organisational expertise that lends stability to a relationship.

In line with the "national champion” strategy developed by European countries, the 
partner headquarters are mainly domestic during the whole period of study, with some in the European Union (EU), which can be associated with participation in European programmes and consortia, and very few in the rest of the world.

In general, partners are either low- or high-technology firms with only approximately $10 \%$ in the medium category throughout the whole period. However, evidence suggests that high-tech partners have a higher presence in the pre-crisis period.

\section{RESULTS}

In order to characterise the collaborations in the defence industry, we use a cluster analysis in each sub-period. As a classification model, we use the hierarchical ${ }^{9}$ agglomerative $^{10}$ method, which is an exploratory data analysis tool that aims to sort different contracts into groups, that is, into similar categories of contracts (Blei and Lafferty 2009). In order to identify different contracting profiles, the type of collaboration, the object of the contract, the duration and the investment level are taken into account.

We used Ward's method because it performed significantly better than other clustering procedures (single linkage, complete linkage, average linkage; Blashfield 1976). Ward’s method creates groups that minimise variance within the clusters (Ward 1963). The measure used for calculating the distance between groups and group elements was the squared Euclidean distance. One advantage of this measure is that the distance between any two objects is not affected by the addition of new objects to the analysis.

Results indicate the existence of three different groups for each sub period and their different characteristics can be seen in table 3.

\section{INSERT TABLE 3}

Table 3 presents the groups found in the cluster analyses for the three different periods studied and the characteristics associated to the contract of each group. First, it can be observed that the three groups in the pre-crisis period are the most heterogeneous in terms of the number of contracts, contrasting with the more homogeneous groups in the last period. Starting with the categories analysed (object, type and importance) each cell collects the percentage of contracts with that feature within the group. From the point of view of the object of the contract, the periods analysed show different patterns across

\footnotetext{
${ }^{9}$ Hierarchical means that all clusters formed consist of mergers of previously formed clusters.

${ }^{10}$ Agglomerative indicates that the method begins with as many clusters as there are observations and end with a single cluster containing all observations.
} 
groups. In the pre-crisis period, the groups had very different objectives. Vehicles and armament are concentrated in group 1.1, communication and inputs in group 1.2 and electronics, communication and software in group 1.3. During the crisis, the importance of electronics in each group is higher than in the pre-crisis period, whereas the incidence of armament and communication decreases, being concentrated in group 2.2. The prominence of technical support is remarkable, compared to the first period, and is mainly concentrated in group 2.1. After the crisis, the relevance of electronics is high in the three groups. The object of the collaborations of the different groups seems to intermingle over the period, blurring the differences among them, which can be interpreted as an increasing relevance of other economic sectors in technological collaborations with the Spanish MoD.

With regard to the type of agreement, in the pre-crisis period, vertical agreements were concentrated in groups 1.1 and 1.2. During the crisis, the relevance of vertical agreements increased, such that all contracts in groups 2.2 and 2.3 are of this type, although its presence in group 2.1 decreases. In the crisis period, vertical agreements are present in all groups and more evenly distributed. Conversely, consultancy collaborations present a negative tendency. In the pre-crisis period, they were concentrated especially in group 1.3, where all contracts are consultancy agreements. During the crisis, this type of collaboration is only present in group 2.1. After the crisis, the distribution of consultancy agreements is more homogeneous across groups, but as the total number of collaborations is smaller, their presence decreases. A reverse trend is observed for institutional agreements, which increase in significance after the crisis, and are present in all groups. Therefore, it can be concluded that closer relations with suppliers to obtain tailored results (vertical agreements), and agreements with institutions that can help economic recovery, usually encouraged as part of research programmes, are preferred. Finally, international agreements have a high but concentrated presence in the pre-crisis period ( 0.50 in group 1.1 and 0.11 in group 1.2); they decrease during the crisis period, although they are more evenly distributed, and they recover afterwards. This evidence would be in line with the attempt to develop a common defence market encouraged by the European Commission. However, despite this recovery in all groups, international agreements are still limited, indicating the preference for national partners that can reinforce the national $R \& D$ and maintain the technology base. This evidence also relates to the demand-pull mechanism. Looking at the importance of the collaboration, it can be observed that groups 1 and 3 , in each period, present a longer duration than group 2 (except for the post-crisis period). The 
duration decreased sharply during the crisis period and it recovered slightly afterwards, but the difference between the groups barely changes over the three periods. Total and monthly investment are also different among groups and across periods. Average total investment decreases notably after the crisis, but more interestingly, the three groups are very homogeneous during the crisis period and, although investment differences arise post crisis, these are not as remarkable as before the crisis. Similarly, monthly investment decreases along the three periods, except for group 2.2, which presents the highest monthly investment of the whole period. Due to this value, the crisis period presents the highest divergences in monthly investment, but these decrease in the post crisis period well below the pre-crisis years. These results could be linked to the MoD budget cuts, but also to the "spinning in" of civilian technology as the evolution of the objects' group show, with the latter technology being less expensive than military technology. Moreover, the intensification of the relationships between civilian and military technologies will ensure the timely assimilation of commercial technology (Hayward 2005). This result would be in line with James, Molas-Gallart and Stankiewicz's (2019) claim and evidence found for the US (Mowery 2010).

In summary, we have identified three different types of technology agreements in each of the sub-periods that differ in the variables analysed and among periods. Based on this typology, the next research question would be if differences are also observed between the partners of each group and sub-period with which the agreements are signed. To this end, the variables that reflect different characteristics of the partners, presented in the previous section, are taken into account. Table 4 shows the average value for each variable by group and sub-period.

\section{INSERT TABLE 4}

The number of partners that participate in technological agreements with the Spanish MoD shows a positive trend, despite the reduction in the number of collaborations. In the pre-crisis period, the Spanish MoD has 57 partners that collaborate in the 140 contracts identified. The number of partners is not homogeneously distributed across groups. Group 1.3 is the group with the highest concentration of partners, with 4 firms/institutions that participate in the 29 technological agreements of this group. Group 1.2 follows with each partner participating in more than two technological agreements. Group 1.1 presents the lowest contract/partner ratio. During the crisis period there are more partners collaborating with the $\mathrm{MoD}$ even though the number of contracts in this period has decreased by 25 contracts. The distribution of partners becomes more homogeneous. 
Group 2.1 and group 2.2 nearly replicate the contract/partner ratio of groups 1.1 and 1.2. However, group 2.3 presents the lowest number of contracts per partner. This change in the number of partners seems to be related to the evolution of the size of partners. As can be observed, partners in the pre-crisis period are larger than during the crisis, with the exception of group 2.1. On the contrary, partners in groups 2.2 and 2.3 are the smallest and the second smallest. After the crisis, partners are larger again but smaller than those of the pre-crisis years. Group 3.1 is the exception. This result could be associated to the fact that the number of partners is the closest to the number of contracts.

Partners are more experienced in the post-crisis period. Further, differences among groups decrease as well. Looking at technology intensity, group 1.1 before the crisis includes the three levels of technology intensity, while group 1.2 is almost equally divided between high and low technological intensity, and group 1.3 has the highest technological intensity (86\%). On the contrary, in the second and third sub-period, low technologically intense partners increase their presence in all groups while high technology intensity falls, especially in groups 2.3 and 3.1 .

Being part of a business group also presents a negative tendency and its disparity among the groups increases along the three periods. Before the crisis, more than $80 \%$ of the partners belong to a business group and the differences between the groups are minor. Group 2.1 presents the smallest value during the crisis years (44\%), while groups 2.2 and 2.3 show values well above $80 \%$. The situation changes after the crisis, when two out of three groups (3.1 and 3.2) present values around 50\%. Partners are mainly domestic during the period, except for group 1.1 before the crisis, where $50 \%$ of the partners are internationally based. This result could be associated to participation in international cooperation programmes that decreased sharply with the economic crisis, and that the EU has tried to encourage with the launching of the European Defence Fund. The international partners are mainly European, especially after the crisis. Interestingly, those groups with highest technology intensity (1.3, 2.2 and 3.2 and 3.3) are the groups with more domestic partners, suggesting that the Spanish defence industrial base has incorporated advanced technologies in line with the evidence found by García-Estevez and Trujillo-Baute (2014).

Overall, this evidence indicates that MoD has incorporated new partners. These new partners are smaller but more experienced and more independent, are mainly domestic and are specialised in different technology intensity. 


\section{CONCLUSIONS.}

In this paper we analyse the characteristics of the technological partners of the Spanish MoD over the last twenty years. This period has been divided into three sub periods: precrisis, crisis and post-crisis, which allow us to analyse the evolution of technological agreements over these years. For each sub period, we first try to identify different typologies of collaboration agreements according to their distinctive characteristics (objective of the agreement, type of partner, duration of the agreement and amount of investment). Second, a comparison is made of the different typologies of partners that participate in each of the identified categories.

Based on the results of the cluster analyses, we are able to identify three different profiles of contracting which have been dynamically adapting to the needs of the Spanish MoD. The first profile can be considered as the military technology collaboration and it is associated to the groups 1.1 (from pre-crisis period), 2.1 (crisis) and 3.1 (post-crisis). This profile concentrates on innovations in vehicles and armament. As expected, when developing tailor-made defence products, investments are long term. The evolution of this profile adapts to changes in the Spanish defence market. First, the MoD did not launch any new large programme during the crisis and recovery years. Accordingly, the MoD has been interested in maintaining and renewing the current equipment to cope with the mission assigned, which can explain the increase in the number of technical support contracts. Partners in this profile are very experienced, less technology intense and the most international, even though there is a contraction in international partnerships that can be associated to restrictions in international cooperation programmes. Partners in this profile are the largest. This evidence would suggest that additional efforts should be made to increase the participation of SMEs in technological collaborations to be aligned with the objectives set down by the Ministry of Defence (2015).

The second profile, civil technology collaboration, derived from groups 1.3, 2.3 and 3.3, focused mainly on electronics and communication. The contract type has evolved from consultancy to vertical contracts, suggesting the increasing incorporation of civil innovations in MoD collaborations and more adaptation to the needs and requirements of the MoD. Duration and total investment is high at the beginning but decreases over the periods. Partners are the least experienced, but the most technologically intensive, in contrast with the first profile, indicating the "spinning in" of the leading edge civil technology. Further, partners are mainly domestic, suggesting, on the one hand, that the MoD strategy to build a strong industrial base could take advantage of leading technology 
firms in different sectors. On the other, MoD collaborations with these partners can, as the so-called pull mechanism claims, enhance the development of new technologyintense products. Interestingly, being part of a business group is important in this profile, which would indicate that traditional partners are incorporating leading technology firms and products to be capable of serving new MoD needs, and suggests the evolution of prime contractors for developing system integration capabilities.

Finally, a third profile of contracts, dual technology collaboration, is identified as of groups 1.2, 2.2 and 3.2 and includes mostly contracts whose object combines communication and armament purposes, that is, civil and military technologies. The mere identification of this profile in MoD technological collaborations shows the relevance of the intermingling between civil and military technology in the Spanish defence market and indicates its adaptation to the global market trend. Contracts seem to be concentrated in time but with a noteworthy monthly investment which would denote their dual nature. The presence of international agreements is low and remains comparatively stable over the period, which indicates that the preference for domestic partners is still present and would be coherent with the MoD strategy of developing a robust industry base that could provide MoD needs but also be prepared to compete internationally. Partners are large, experienced and part of business groups (although less importantly at the end of the period), which could be related to the participation of traditional defence partners as highlighted for the civil technology collaborations. The presence of small partners is again marginal. Therefore, additional MoD measures should be implemented to increase the presence of SMEs to achieve a more cohesive industry as highlighted by ministry officials. $^{11}$

\section{INSERT TABLE 5}

Interestingly, the objects of the three profiles seem to accommodate the main functional areas of the technology goals as defined in the defence technology and innovation strategy (DTIS) drawn directly from the defence planning process established by the MoD. In addition, the evolution of the different profiles shows increased adaptation to the evolving DTIS objectives. Accordingly, military profile focuses on vehicles, armament and platforms, and their technical support. These areas resemble the three functional areas highlighted in the DTIS (Armament, Platforms, and Platforms and Critical Assets). The

\footnotetext{
${ }^{11}$ Agustín Conde Bajén, Secretary of State for Defence in 2017, stated that the MoD has striven to develop a more cohesive industry, and to promote and prepare SMEs through R\&D and productive investments (IDS 2017).
} 
civil profile would be associated with the last technological goal, information and communication Technologies and electronics. Dual profile would be associated with the ISTAR concept (Intelligence, Surveillance, Target Acquisition and Reconnaissance), which refers to the integrated capacity to acquire, process, exploit and disseminate intelligence information, with appropriate content and in an appropriate timeframe, enabling it to be used in the planning and development of military operations (Ministry of Defence 2015).

Although DTIS technological goals are long-term objectives, the strategy also draws on a cluster of short and mid-term actions to meet them. In this way, the R\&D results obtained because of these actions can be successfully applied to the development of systems relevant to the armed forces. The identified profiles would belong to this midterm action category that will complement longer projects. Furthermore, throughout the whole period analysed, vertical agreements gain relevance in all profiles, suggesting closer relations with suppliers to obtain tailored results. Furthermore, the experience suggests that these companies would be able to adapt their innovation models to MoD requirements and the preference for national partners would reinforce the national $R \& D$ and technology base. This evidence also relates to the demand-pull mechanism. Altogether, the proposed profiles classification can help to reinforce the public reference guide for defence oriented $R \& D$ and technological innovation goals and to serve as a basis for the prioritisation of private national R\&D activities, as suggested in DTIS. In addition, the post crisis period information can be used to develop targeted interventions aimed at providing a better definition and implementation of future collaborations to reinforce the DTIS objectives, such as international collaborations or increasing the presence of SMEs.

The first step could be to design a menu of contracts depending on the characteristics that define the profiles identified in the analysis. For instance, in the dual profile, it would be interesting to include clauses to encourage technology transfers to the rest of the economy that can help to increase productivity. In the US, similar mechanisms such as cooperative $R \& D$ agreement are said to have promoted positive spillovers in the economy and its absence is considered one of the reasons for the technology gap between Europe and US (Bellais and Guillard 2006). In this way, defining the relevant incentives would increase the integration between the civilian and defence industrial and technological bases to create further synergies and interactions (Bellais and Guillard 2006). In addition, with an adequate contract design the Spanish MoD can be more active, not only facilitating the 
modernisation of the defence sector as stated in DTIS, but also influencing the evolution of the Spanish defence sector and being able to share the rewards when they materialise. Similar recommendations have been suggested by Mazzucato and Robinson (2018) for NASA.

Second, by having a priori information on the most probable type of partner that could take part in each profile, the MoD could develop its organisational structure in ways that would welcome exploration, risk and learning. This would enhance communication and trust between all actors, helping extend relationships and foresee anticipated needs and potential solutions beyond the current market relationships and perceptions to overcome weaknesses (Mazzucato 2018). Additionally, as these lasting relationships can give a competitive edge to partners that can improve economic performance and increase exports, collaboration contracts can attract very dynamic firms. Since defence markets are uncertain and volatile, and depend on political conditions, it might also be interesting for technological collaborations to leverage partners' capabilities and dynamism to include, to some extent, possible demand opportunities in national as well as overseas markets as a way of reinforcing incentives to collaborate and partners' potential economic benefits. Castellacci and Fevolden (2014) show the positive effects of enlarging demand opportunities in this sense for the Norwegian defence industrial base.

Our results are especially relevant in light of the European Defence landscape changes that try to reduce traditional fragmentation and the new mechanisms designed to leap forward in terms of collaborations through funding, in particular from the European Defence fund, to promote collaborative defence $\mathrm{R} \& \mathrm{D}$. The better the collaboration design is, the greater the increase in innovation and absorptive capacity of the partners (Zahra and George 2002), and this can improve the Spanish industry's competitive advantage for participation in the collaborative projects promoted by the EU. Moreover, in order to achieve a more cohesive industry, additional efforts should be made to increase the participation of SMEs in technological collaborations to be aligned with the objectives set down by the Ministry of Defence (2015).

Based on this detailed analysis of technological collaborations, future research should explore the development of evaluation measures to improve programme assessment and alignment with the strategy and mission of the MoD. Moreover, looking at partners' economic and technological results after the collaborations, and also at the relation between results and collaboration characteristics could provide valuable information to define a menu of contracts designed to increase the success of technological collaboration 
and share risks and rewards in a better way.

\section{Acknowledgements}

We are grateful to two anonymous referees and participants at the 23rd annual International Conference on Economics and Security and VII National Meeting on Defence and Security R\&D (DESEi+d 2019) for helpful suggestions and comments.

\section{Funding}

This research was supported by project grants ECO2016-77-P (AEI/FEDER, UE), ECO2016-76255-P and PID2019-106642GB-I00, project 27267 CUD-UNIZAR, project CUD 2018-12 and the COMPETE (S52_20R) research group (Government of Aragón Spain- and FEDER 2020-2022 "Construyendo Europa desde Aragón").

\section{REFERENCES}

Álvarez, I. and A. Fonfría, 2000. "Estructura e Innovación en la Industria de Defensa Española.” Economistas 85: 102-121.

Antolín-López, R., J. Céspedes-Lorente, N. García-de-Frutos, J. Martínez-del-Río and M. Pérez-Valls. 2015. "Fostering Product Innovation: Differences Between New Ventures and Established Firms.” Technovation 41-42: 25-37. doi: 10.1016/j.technovation.2015.02.002.

Aristei, D., M. Vecchi, and F. Venturini. 2016. "University and Inter-Firm R\&D Collaborations: Propensity and Intensity of Cooperation in Europe.” The Journal of Technology Transfer 41 (4): 841-871. doi: 10.1007/s10961-015-9403-1.

Arteaga, F. 2013. The Coming Defences: Criteria for the Restructuring of Defence in Spain. Real Instituto Elcano Policy Paper. Madrid.

Audretsch D. B., A.N. Link and J.T. Scott. 2002. "Public/Private Technology Partnerships: Evaluating SBIR-Supported Research.” Research Policy 31 (1): 145158. doi: 10.1016/S0048-7333(00)00158-X.

Badillo, E., F. Llorente Galera and R. Moreno Serrano. 2017. “Cooperation in R\&D, Firm Size and Type of Partnership: Evidence for the Spanish Automotive Industry.” European Journal of Management and Business Economics 26 (1): 123-143. doi: 10.1108/EJMBE-07-2017-008.

Baum, J.A.C., T. Calabrese and B.S. Silverman. 2000. “Don’t Go It Alone: Alliance Network Composition and Startups' Performance in Canadian Biotechnology.” Strategic Management Journal 21 (3): 267-294. doi: 10.1002/(SICI)10970266(200003)21:33.0.CO;2-8. 
Belin, J., M. Guille, N. Lazaric and V. Mérindol, V. 2019. "Defense firms adapting to Major Changes in the French R\&D Funding System.” Defence and Peace Economics 30(2): 142-158. doi: 10.1080/10242694.2018.1461790.

Bellais, R. and R. Guichard. 2006. "Defense Innovation, Technology Transfers and Public Policy.” Defence and Peace Economics 17(3), 273-286, doi: $10.1080 / 10242690600645274$.

Bellais, R. 2009. "Defence Innovation at Any (Out of Control) Cost? The Stalemate of Today’s R\&D Policy and Alternative Model.” The economics of Peace and Security Journal 4 (1): 5-12. doi: 10.1080/10242690600645274.

Berg, H., A. Ofstad Presterud and M. Øhrn. 2019. "Military Off the Shelf Procurements: A Norwegian Case Study.” Defence and Peace Economics 30(1): 98-110, DOI: 10.1080/10242694.2017.1342182. doi: 10.1080/10242694.2017.1342182.

Blashfield, R. K. 1976. "Mixture Model Tests of Cluster Analysis: Accuracy of Four Agglomerative Hierarchical Methods.” Psychological Bulletin 83(3): 377. doi: 10.1037/0033-2909.83.3.377.

Blei, D., and J. Lafferty. 2009. “Topic Models.” In Text Mining: Classification, Clustering, and Applications (pp. 71- 94). Edited by A. Srivastava and M. Sahami. Boca Raton, FL: Taylor \& Francis Group.

Brogaard, L. 2017. "The Impact of Innovation Training on Successful Outcomes in Public-Private Partnerships.” Public Management Review 19 (8): 1184-1205. doi:10.1080/14719037.2016.1272710. doi: 10.1080/14719037.2016.1272710.

Castellacci, F and A. Fevolden. 2014. "Capable Companies or Changing Markets? Explaining the Export Performance of Firms in the Defence Industry.” Defence and Peace Economics 25(6): 549-575. doi: 10.1080/10242694.2013.857451.

Daffiix, S. and Y. Jacquin. 2009. "Defence R\&D and National R\&D Systems: A European Outlook.” The Economics of Peace and Security Journal 4 (1): 13-22.

Duch-Brown, N., A. Fonfría and E. Trujillo-Baute. 2014. "Market Structure and Technical Efficiency of Spanish Defence Contractors." Defence and Peace Economics 25 (1): 23-38. doi: 10.1080/10242694.2013.857461.

Dunne, J. P. and R. P. Smith. 2016. "The Evolution of Concentration in the Arms Market." The Economics of Peace and Security Journal 11 (1): 12-17. doi: 10.15355/epsj.11.1.12.

Dyer, J. H., and W. Chu. 2003. “The Role of Trustworthiness in Reducing Transaction Costs and Improving Performance: Empirical Evidence from the United States, 
Japan, and Korea.” Organization Science $14 \quad$ (1): 57-68. doi: 10.1287/orsc.14.1.57.12806.

Edler, J. and L. Georghiou. 2007. "Public Procurement and Innovation-Resurrecting the Demand Side.” Research Policy 36(7) 949-963. doi: 10.1016/j.respol.2007.03.003 European commission. 2018. “From Horizon 2020 to Horizon Europe.” Monitoring Flash \#1.1 Country Participation. European Commission.

European commission. 2019. “From Horizon 2020 to Horizon Europe.” Monitoring flash \#3 international cooperation. European Commission.

Ferreira, J. J., C. I. Fernandes, H. Alves and M.L. Raposo. 2015. “Drivers of Innovation Strategies: Testing the Tidd and Bessant (2009) Model.” Journal of Business Research 68 (7): 1395-1403. doi: 10.1016/j.jbusres.2015.01.021.

Franco, C., and M. Gussoni. 2014. "The role of firm and national level factors in fostering R\&D cooperation: a cross country comparison.” The Journal of Technology Transfer 39 (6): 945-976. doi: 10.1007/s10961-013-9306-y.

Fuchs, E.R. H. 2010. "Rethinking the Role of the State in Technology Development: DARPA and the Case for Embedded Network Governance.” Research Policy 39 (9) 1133-1147. doi: 10.1016/j.respol.2010.07.003.

García-Estevez, J. and E. Trujillo-Baute. 2014. "Drivers of R\&D Investment in the Defence Industry: Evidence from Spain.” Defence and Peace Economics 25 (1): 39-49. doi: 10.1080/10242694.2013.857464.

Hagedoorn, J., A. Link and N.S. Vonortas. 2000. “Research Partnerships.” Research Policy 29(4-5): 567-586. doi: 10.1016/S0048-7333(99)00090-6.

Ham, R.M. and D. Mowery. 1998. "Improving the Effectiveness of Public-Private R\&D Collaboration: Case Studies at a US Weapons Laboratory.” Research Policy 26(6): pages 661-675. doi: 10.1016/S0048-7333(97)00041-3.

Hartley, K. 2008. “Collaboration and European Defence Industrial Policy.” Defence and Peace Economics 19 (4): 303-315. doi: 10.1080/10242690802221585.

Hartley, K. 2018. "The Profitability of Non-Competitive Defence Contracts: The UK Experience." Defence and Peace Economics 29 (6): 577-594. doi: 10.1080/10242694.2017.1287157.

Hayward, K. 2005. “'I have seen the future and it works': the US defence industry transformation - Lessons for the UK defence industrial base.” Defence and Peace Economics 16(2), 127-141. doi: 10.1080/1024269032000110559C.

IDS (Information and Design Solutions). 2017. Spain, Defence and Security Industry 
2016: R\&D, the Strategic Approach. Madrid: Information and Design Solutions. James, A. D., J. Molas-Gallart and R. Stankiewicz. 2019. The Defence Technology Procurement System and New Modes of Knowledge Accumulation. ICES 2019, 26-28 June Madrid. http://www.ingenio.upv.es/en/news/jordi-molas-defencetechnology-procurement-system-and-new-modes-knowledge-accumulationices\#.XcBas3jQgow.

James, A., 2004. U.S. Defence R\&D Spending: An Analysis of the Impacts. Rapporteur's Report for the EURAB Working Group ERA Scope and Vision, EURAB 04.011, Manchester,http://europa.eu.int/comm/research/eurab/pdf/recommendations10.pdf

Li, X., Y. Zheng and C. L. Wang. 2016. "Inter-firm Collaboration in New Product Development in Chinese Pharmaceutical Companies.” Asia Pacific Journal of Management 33 (1), 165-193. doi: 10.1007/s10490-015-9451-y.

Linde, L.M. 2014. “La recuperación de la Economía Española.” Conference of the governor of Bank of Spain at Coloquio Asociación para el Progreso de la Dirección, Valencia. Banco de España. Eurosistema. Retreived from https://www.bde.es/f/webbde/GAP/Secciones/SalaPrensa/IntervencionesPublicas/ Gobernador/Arc/Fic/linde250614.pdf

Martí Sempere, C. 2015. “A Survey of Performance Issues in Defence Innovation.” Defence and Peace Economics 28 (3): 319-343. doi:10.1080/10242694.2015.1072377.

Martí Sempere, C. 2018. "What is Known about Defence Research and Development Spill-Overs?, Defence and Peace Economics 29(3): 225-246, DOI: 10.1080/10242694.2016.1239364.

Matt, M., Robin, S., and Wolff, S. 2012. “The influence of public programs on inter-firm R\&D collaboration strategies: project-level evidence from EU FP5 and FP6”. The Journal of Technology Transfer, 37(6): 885-916. doi: 10.1007/s10961-011-9232-9.

Mazzucato, M. and D. K. R. Robinson. 2018. “Co-Creating and Directing Innovation Ecosystems? NASA's Changing Approach to Public-Private Partnerships in LowEarth Orbit.” Technological Forecasting \& Social Change 136: 166-177. doi: 10.1016/j.techfore.2017.03.034.

Mazzucato, M. 2016, “From Market Fixing to Market-Creating: A New Framework for Innovation Policy.” Industry and Innovation 23(2), 140-156. doi: 10.1080/13662716.2016.1146124.

Mazzucato, M., 2013. The Entrepreneurial State: Debunking Public vs. Private Sector. 
Myths. Anthem Press, London.

Mazzucato, M. 2018. "Mission-Oriented Innovation Policies: Challenges and Opportunities.” Industrial and Corporate Change 27(5): 803-815. doi: 10.1093/icc/dty034.

Ministerio de Defensa. 2017. La industria de Defensa en España. Informe 2016. Madrid. Publicaciones de Defensa.

Ministerio de Defensa. 2015. Estrategia de Tecnología e Innovación para la defensa. ETID-2015. Madrid. Publicaciones de Defensa.

Molas-Gallart, J. 1997. "Which Way To Go? Defence Technology and the Diversity of 'Dual-Use' Technology Transfer.” Research Policy 26 (3): 367-385. doi: 10.1016/S0048-7333(97)00023-1.

Montoro-Sanchez, A., E. M. Mora-Valentin and L.A. Guerras-Martín. 2006. “R\&D Cooperative Agreements Between Firms and Research Organisations: A Comparative Analysis of the Characteristics and Reasons Depending on the Nature of the Partner.” International Journal of Technology Management 35 (1-4): 156181. doi: 10.1504/IJTM.2006.009233.

Mowery, D. C, 2010. "R\&D and Innovation”. In Handbook of the Economics of Innovation, vol. 2, edited by B.H. Hall and N. Rosenberg. London: North Holland. 1219-1256. 10.1016/S0169-7218(10)02013-7.

Mowery, D. C. 2012. "Defence-related R\&D as a Model for "Grand Challenges" Technology Policies.” Research Policy 41(10): 1703- $1715 . \quad$ doi: 10.1016/j.respol.2012.03.027.

Mowery, D. C., and B. N. Sampat. 2005. "Universities in National Innovation Systems.” In The Oxford Handbook of Innovation, edited by J. Fagerberg, D. C. Mowery, and R. Nelson, 209-239. New York: Oxford University Press.

OECD. 2011. ISIC Rev.3 Technology Intensity Definition. OECD, July. https://www.oecd.org/sti/ind/48350231.pdf.

Outdot, J.M. 2010. “Performance and Risks in the Defence Procurement Sector.” Journal $\begin{array}{lllll}\text { of } & \text { Public } & \text { Policy } & 30 & \text { (2): }\end{array}$ doi: https://doi.org/10.1017/S0143814X10000073

Pérez Muinelo, F. 2015. El Gasto de Defensa en España 1946-2015. Ministerio de Defensa. Madrid.

Rihoux, B. 2006. “Qualitative Comparative Analysis (QCA) and Related Systematic Comparative Methods Recent Advances and Remaining Challenges for Social 
Science Research.” International Sociology 21 (5): 679-706. doi:10.1177/0268580906067836. .

Saal, D.S. 2001. “The Impact of Procurement-Driven Technological Change on US Manufacturing Productivity Growth.” Defence and Peace Economics 12 (6): 537568. doi: 10.1080/10430710108405002.

Schmid, J. 2018. "The Diffusion of Military Technology." Defence and Peace Economics 29 (6): 595-613. doi: 10.1080/10242694.2017.1292203

SIPRI. 2020. Arms and military expenditure: International arms transfers. https://www.sipri.org.

Smit, W.A., B. Elzen and B. Enserink. 1998. "Coordination in Military Socio-Technical Networks: Military Needs, Requirements and Guiding Principles.” In Getting New Technologies Together. Studies in Making Socio-technical Order. Edited by Disco, C. and B. van der Meulen. Walter de Gruyter, Berlin, 71-105.

Soete, L. and A. Arundel. 1993. An Integrated Approach to European Innovation and Technology Diffusion Policy: A Maastrcht Memorandum. Commission of the European Communities, SPRINT programme: Luxembourg, Luxembourg.

te Kulve, H. \& W.A. Smit. 2003. "Civilian-Military Co-Operation Strategies in Developing New Technologies.” Research Policy 32(6): 955-970. doi: 10.1016/S0048-7333(02)00105-1.

Torregrosa-Hetland, S., A. Pelkonen, J. Oksanen and Ao. Kander. 2019. “The Prevalence of Publicly Stimulated Innovations -A Comparison of Finland and Sweden, 19702013.” Research Policy 48 (6): 1373-1384. doi: 10.1016/j.respol.2019.02.001.

Ward, J. H. 1963. “Hierarchical Grouping to Optimize an Objective Function.” Journal of the American Statistical Association 58: 236-244. doi: 10.2307/2282967.

Zahra, S. A., and G. George. 2002. "Absorptive Capacity: A Review, Reconceptualization, and Extension.” Academy of Management Review 27 (2): 185203. doi: $10.2307 / 4134351$. 
Table 1: Distribution of agreements, organisations and year of investment

\begin{tabular}{|c|c|c|c|}
\hline Period & Investment year & $\begin{array}{c}\text { Number of } \\
\text { Agreements }\end{array}$ & $\begin{array}{c}\text { Number of } \\
\text { Organisations }\end{array}$ \\
\hline \multirow{9}{*}{ Pre-crisis } & 1999 & 1 & 1 \\
\hline & 2000 & 3 & 2 \\
\hline & 2001 & 3 & 2 \\
\hline & 2002 & 4 & 3 \\
\hline & 2003 & 4 & 4 \\
\hline & 2004 & 19 & 10 \\
\hline & 2005 & 47 & 26 \\
\hline & 2006 & 36 & 18 \\
\hline & 2007 & 23 & 12 \\
\hline \multirow{7}{*}{ Crisis } & 2008 & 23 & 17 \\
\hline & 2009 & 16 & 9 \\
\hline & 2010 & 8 & 6 \\
\hline & 2011 & 40 & 34 \\
\hline & 2012 & 2 & 2 \\
\hline & 2013 & 11 & 6 \\
\hline & 2014 & 15 & 12 \\
\hline \multirow{3}{*}{ Post-crisis } & 2015 & 38 & 27 \\
\hline & 2016 & 11 & 9 \\
\hline & 2017 & 18 & 12 \\
\hline \multicolumn{2}{|c|}{ TOTAL } & 322 & $108^{(1)}$ \\
\hline
\end{tabular}

${ }^{(1)}$ Some organisations appear in more than one year. 
Table 2: Characteristics of Collaborations and Partners

\begin{tabular}{|c|c|c|c|c|c|c|c|c|c|c|}
\hline & \multirow[t]{2}{*}{ VARIABLES } & \multicolumn{2}{|c|}{$\begin{array}{c}1999-2007 \\
(N=140)\end{array}$} & \multicolumn{2}{|c|}{$\begin{array}{c}2008-2014 \\
(N=115)\end{array}$} & \multicolumn{2}{|c|}{$\begin{array}{c}2015-2017 \\
(N=67)\end{array}$} & \multicolumn{2}{|c|}{$\begin{array}{c}1999-2017 \\
(\mathrm{~N}=322)\end{array}$} & \multirow{2}{*}{$\begin{array}{c}\text { Dunn- } \\
\text { Bonferroni }\end{array}$} \\
\hline & & Mean & S.d. & Mean & S.d. & Mean & S.d. & Mean & S.d. & \\
\hline \multicolumn{11}{|c|}{ CHARACTERISTICS OF COLLABORATION } \\
\hline \multirow{8}{*}{$\frac{\overline{\mathscr{U}}}{\frac{\mathscr{\theta}}{0}}$} & Armament & 0.09 & 0.28 & 0.06 & 0.24 & 0.06 & 0.24 & 0.07 & 0.26 & \\
\hline & Electronics & 0.31 & 0.46 & 0.37 & 0.49 & 0.33 & 0.47 & 0.34 & 0.47 & \\
\hline & Communication & 0.21 & 0.41 & 0.16 & 0.36 & 0.21 & 0.41 & 0.19 & 0.39 & \\
\hline & Software & 0.11 & 0.32 & 0.10 & 0.31 & 0.16 & 0.37 & 0.12 & 0.33 & \\
\hline & Inputs & 0.08 & 0.27 & 0.08 & 0.27 & 0.06 & 0.24 & 0.07 & 0.26 & \\
\hline & Tech_support & 0.04 & 0.19 & 0.10 & 0.30 & 0.00 & 0.00 & 0.05 & 0.22 & $3-2 * * 1-2 *$ \\
\hline & Vehicle & 0.11 & 0.32 & 0.10 & 0.31 & 0.16 & 0.37 & 0.12 & 0.33 & \\
\hline & Others & 0.06 & 0.23 & 0.03 & 0.16 & 0.01 & 0.12 & 0.04 & 0.19 & \\
\hline \multirow{4}{*}{$\sum_{\text {Ḋ }}^{\stackrel{D}{1}}$} & Vertical & 0.66 & 0.47 & 0.63 & 0.48 & 0.70 & 0.46 & 0.66 & 0.47 & \\
\hline & Consultancy & 0.29 & 0.46 & 0.17 & 0.37 & 0.10 & 0.31 & 0.21 & 0.41 & $3-1 * * 2-1 *$ \\
\hline & Institutional & 0.04 & 0.20 & 0.20 & 0.40 & 0.19 & 0.40 & 0.13 & 0.34 & $1-3 * * 1-2 * * *$ \\
\hline & International & 0.19 & 0.40 & 0.09 & 0.28 & 0.13 & 0.34 & 0.14 & 0.35 & \\
\hline \multirow{10}{*}{ 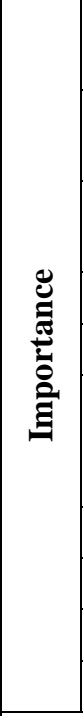 } & $\begin{array}{l}\text { Total investment } \\
\text { (median) }^{(1)}\end{array}$ & $\begin{array}{r}6619 \\
(863) \\
\end{array}$ & 25295 & $\begin{array}{r}790 \\
(250) \\
\end{array}$ & 1943.75 & $\begin{array}{r}393 \\
(260) \\
\end{array}$ & 459.22 & $\begin{array}{r}3242 \\
(375) \\
\end{array}$ & 16949 & $3-1 * * * 2-1 * * *$ \\
\hline & \begin{tabular}{|l|}
$\begin{array}{l}\text { Duration (months) } \\
\text { (median) }\end{array}$ \\
\end{tabular} & $\begin{array}{r}32.83 \\
(24) \\
\end{array}$ & 23.07 & $\begin{array}{r}19.95 \\
(16) \\
\end{array}$ & 15.92 & $\begin{array}{r}22.26 \\
(24) \\
\end{array}$ & 12.83 & $\begin{array}{r}26.03 \\
(24) \\
\end{array}$ & 19.77 & $2-1 * * * 3-1 * *$ \\
\hline & Short & 0.16 & 0.37 & 0.48 & 0.50 & 0.31 & 0.47 & 0.30 & 0.46 & $\begin{array}{c}1-3 * 1-2 * * 3- \\
2 *\end{array}$ \\
\hline & Medium & 0.40 & 0.49 & 0.27 & 0.45 & 0.34 & 0.48 & 0.34 & 0.47 & \\
\hline & Long & 0.44 & 0.50 & 0.25 & 0.44 & 0.34 & 0.48 & 0.35 & 0.48 & $2-1 * *$ \\
\hline & $\begin{array}{l}\text { Monthly } \\
\text { Investment }^{(1)} \\
\text { (median) }\end{array}$ & $\begin{array}{r}125.13 \\
(35.42)\end{array}$ & 295.89 & $\begin{array}{r}133.69 \\
(18.32)\end{array}$ & 466.85 & $\begin{array}{r}26.67 \\
(13.11)\end{array}$ & 32.91 & $\begin{array}{r}107.70 \\
(19.73)\end{array}$ & 342.46 & $3-1 * * * 2-1 * *$ \\
\hline & \begin{tabular}{|l|} 
Low \\
\end{tabular} & 0.18 & 0.38 & 0.31 & 0.47 & 0.33 & 0.47 & 0.26 & 0.44 & $1-2 * 1-3 *$ \\
\hline & Medium & 0.41 & 0.49 & 0.43 & 0.50 & 0.51 & 0.50 & 0.44 & 0.50 & \\
\hline & High & 0.35 & 0.48 & 0.21 & 0.41 & 0.16 & 0.37 & 0.26 & 0.44 & $3-1 * * 2-1 *$ \\
\hline & Very high & 0.06 & 0.23 & 0.04 & 0.20 & 0.00 & 0.00 & 0.04 & 0.20 & \\
\hline \multicolumn{11}{|c|}{ CHARACTERISTICS OF PARTNERS ${ }^{(2)}$} \\
\hline \multicolumn{2}{|c|}{$\begin{array}{l}\text { Size (No. employees) } \\
(\text { median })\end{array}$} & $\begin{array}{r}3922 \\
(554) \\
\end{array}$ & 9150 & \begin{tabular}{|r|}
2013 \\
$(355)$ \\
\end{tabular} & 4020 & $\begin{array}{r}2112 \\
(207) \\
\end{array}$ & 4026 & $\begin{array}{r}2950 \\
(423) \\
\end{array}$ & 7020 & $3-1 * * 2-1 *$ \\
\hline \multicolumn{2}{|c|}{$\begin{array}{l}\text { Experience } \\
\text { (median) }\end{array}$} & $\begin{array}{r}28.83 \\
(21) \\
\end{array}$ & 26.66 & $\begin{array}{r}43.96 \\
(23) \\
\end{array}$ & 82.91 & $\begin{array}{r}72.10 \\
(28) \\
\end{array}$ & 132.01 & $\begin{array}{r}43.17 \\
(24) \\
\end{array}$ & 81.03 & $1-3 *$ \\
\hline \multicolumn{2}{|c|}{ Group } & 0.91 & 0.29 & 0.69 & 0.46 & 0.58 & 0.49 & 0.77 & 0.42 & $3-1 * * * 2-1 * * *$ \\
\hline \multirow{3}{*}{ 오 } & Domestic & 0.81 & 0.40 & 0.91 & 0.28 & 0.88 & 0.33 & 0.86 & 0.35 & $1-2^{*}$ \\
\hline & European_Union & 0.14 & 0.35 & 0.07 & 0.26 & 0.10 & 0.31 & 0.11 & 0.31 & \\
\hline & Rest_of_world & 0.05 & 0.22 & 0.02 & 0.13 & 0.01 & 0.12 & 0.03 & 0.17 & \\
\hline \multirow{2}{*}{ ڤٌ } & High_tech & 0.50 & 0.50 & 0.34 & 0.47 & 0.34 & 0.48 & 0.41 & 0.49 & $2-1 *$ \\
\hline & Medium_tech & 0.10 & 0.31 & 0.12 & 0.33 & 0.11 & 0.31 & 0.11 & 0.31 & \\
\hline
\end{tabular}


(1) Thousands of euros. S.d. Standard Deviation. ${ }^{(2)}$ The number of observations of each variable and sub period differs because some are missing. However, the minimum number of observations are 126, 85 and 51 for pre-crisis, crisis and post-crisis respectively. ${ }^{*} \mathrm{p}<0.05 ;{ }^{* *} \mathrm{p}<0.01 ;{ }^{* * *} \mathrm{p}<0.001$.

Table 3: Identification of groups and typologies of collaborations.

\begin{tabular}{|c|c|c|c|c|c|c|c|c|c|c|}
\hline \multirow{2}{*}{\multicolumn{2}{|c|}{ VARIABLES }} & \multicolumn{3}{|c|}{ Pre-crisis: 1999-2007 } & \multicolumn{3}{|c|}{ Crisis: 2008-2014 } & \multicolumn{3}{|c|}{ Post-crisis: 2015-2017 } \\
\hline & & $\begin{array}{c}\text { Grupo } \\
1.1 \\
\end{array}$ & $\begin{array}{c}\text { Grupo } \\
1.2 \\
\end{array}$ & $\begin{array}{c}\text { Grupo } \\
1.3 \\
\end{array}$ & $\begin{array}{c}\text { Grupo } \\
2.1 \\
\end{array}$ & $\begin{array}{c}\text { Grupo } \\
2.2 \\
\end{array}$ & $\begin{array}{c}\text { Grupo } \\
2.3 \\
\end{array}$ & $\begin{array}{c}\text { Grupo } \\
3.1 \\
\end{array}$ & $\begin{array}{c}\text { Grupo } \\
3.2 \\
\end{array}$ & $\begin{array}{c}\text { Grupo } \\
3.3 \\
\end{array}$ \\
\hline \multicolumn{2}{|c|}{ No. Observations } & 38 & 73 & 29 & 43 & 38 & 34 & 22 & 24 & 21 \\
\hline \multirow{8}{*}{ 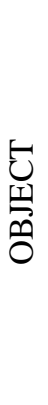 } & Armament & 0.13 & 0.10 & 0.00 & 0.00 & 0.13 & 0.06 & 0.08 & 0.08 & 0.00 \\
\hline & Electronics & 0.26 & 0.30 & 0.38 & 0.28 & 0.42 & 0.44 & 0.33 & 0.33 & 0.43 \\
\hline & Communication & 0.13 & 0.23 & 0.24 & 0.09 & 0.24 & 0.15 & 0.25 & 0.25 & 0.24 \\
\hline & Software & 0.11 & 0.10 & 0.17 & 0.02 & 0.16 & 0.15 & 0.13 & 0.13 & 0.19 \\
\hline & Inputs & 0.03 & 0.14 & 0.00 & 0.16 & 0.00 & 0.06 & 0.04 & 0.04 & 0.00 \\
\hline & Tech_support & 0.03 & 0.03 & 0.07 & 0.21 & 0.05 & 0.00 & 0.00 & 0.00 & 0.00 \\
\hline & Vehicle & 0.26 & 0.07 & 0.03 & 0.19 & 0.00 & 0.12 & 0.13 & 0.13 & 0.14 \\
\hline & Others & 0.05 & 0.04 & 0.10 & 0.05 & 0.00 & 0.03 & 0.04 & 0.04 & 0.00 \\
\hline \multirow{4}{*}{$\frac{1}{2}$} & Vertical & 0.89 & 0.81 & 0.00 & 0.02 & 1.00 & 1.00 & 0.50 & 0.50 & 0.86 \\
\hline & Consultancy & 0.00 & 0.16 & 1.00 & 0.44 & 0.00 & 0.00 & 0.21 & 0.21 & 0.10 \\
\hline & Institutional & 0.11 & 0.03 & 0.00 & 0.53 & 0.00 & 0.00 & 0.29 & 0.29 & 0.05 \\
\hline & International & 0.50 & 0.11 & 0.00 & 0.07 & 0.08 & 0.12 & 0.13 & 0.13 & 0.14 \\
\hline \multirow{10}{*}{ 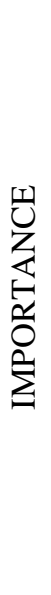 } & Duration (months) & 49.82 & 18.88 & 45.69 & 24.47 & 7.28 & 28.38 & 28.96 & 28.96 & 8.12 \\
\hline & Short & 0.00 & 0.29 & 0.03 & 0.42 & 0.97 & 0.00 & 0.00 & 0.00 & 0.95 \\
\hline & Medium & 0.05 & 0.71 & 0.07 & 0.28 & 0.00 & 0.56 & 0.54 & 0.54 & 0.00 \\
\hline & Long & 0.95 & 0.00 & 0.90 & 0.30 & 0.03 & 0.44 & 0.46 & 0.46 & 0.05 \\
\hline & $\begin{array}{c}\text { Monthly } \\
\text { Investments }^{(1)}\end{array}$ & 247 & 63 & 121 & 61.00 & 307 & 31 & 25 & 25 & 51 \\
\hline & Low & 0.18 & 0.21 & 0.10 & 0.47 & 0.16 & 0.29 & 0.00 & 0.00 & 0.00 \\
\hline & Medium & 0.29 & 0.55 & 0.24 & 0.37 & 0.42 & 0.53 & 0.92 & 0.92 & 0.57 \\
\hline & High & 0.39 & 0.22 & 0.62 & 0.14 & 0.32 & 0.18 & 0.08 & 0.08 & 0.43 \\
\hline & Very high & 0.13 & 0.03 & 0.03 & 0.02 & 0.11 & 0.00 & 0.00 & 0.00 & 0.00 \\
\hline & $\begin{array}{c}\text { Total } \\
\text { Investment(1) }\end{array}$ & 16917 & 876 & 7583 & 806 & 712 & 858 & 700 & 700 & 297 \\
\hline
\end{tabular}

(1) Thousands of euros 
Table 4: Characteristics of partners by typologies of collaborations.

\begin{tabular}{|c|c|c|c|c|c|c|c|c|c|c|}
\hline \multirow{2}{*}{\multicolumn{2}{|c|}{ VARIABLES }} & \multicolumn{3}{|c|}{ Pre-crisis: 1999-2007 } & \multicolumn{3}{|c|}{ Crisis: 2008-2014 } & \multicolumn{3}{|c|}{ Post-crisis: 2015-2017 } \\
\hline & & $\begin{array}{c}\text { Group } \\
1.1\end{array}$ & $\begin{array}{c}\text { Group } \\
1.2\end{array}$ & $\begin{array}{c}\text { Group } \\
1.3\end{array}$ & $\begin{array}{c}\text { Group } \\
2.1\end{array}$ & $\begin{array}{c}\text { Group } \\
2.2\end{array}$ & $\begin{array}{c}\text { Group } \\
2.3\end{array}$ & $\begin{array}{c}\text { Group } \\
3.1\end{array}$ & $\begin{array}{c}\text { Group } \\
3.2\end{array}$ & $\begin{array}{c}\text { Group } \\
3.3\end{array}$ \\
\hline \multicolumn{2}{|c|}{ No. Observations } & 38 & 73 & 29 & 43 & 38 & 34 & 22 & 24 & 21 \\
\hline \multicolumn{2}{|c|}{ No. Partners } & 21 & 32 & 4 & 24 & 18 & 24 & 19 & 12 & 17 \\
\hline \multicolumn{2}{|l|}{ Size } & 4202 & 2888 & 6183 & 6410 & 491 & 847 & 724 & 3316 & 2267 \\
\hline \multicolumn{2}{|c|}{ Experience } & 40.47 & 25.37 & 24.54 & 69.13 & 34.20 & 25.33 & 97.62 & 83.68 & 32.55 \\
\hline \multirow{3}{*}{ ڤัँّ้ } & High_tech & 0.29 & 0.44 & 0.86 & 0.34 & 0.39 & 0.27 & 0.14 & 0.39 & 0.50 \\
\hline & Medium_tech & 0.26 & 0.07 & 0.00 & 0.03 & 0.19 & 0.15 & 0.10 & 0.17 & 0.05 \\
\hline & Low_tech & 0.44 & 0.49 & 0.14 & 0.63 & 0.42 & 0.58 & 0.76 & 0.43 & 0.45 \\
\hline \multicolumn{2}{|c|}{ Group } & 0.82 & 0.95 & 0.97 & 0.44 & 0.84 & 0.85 & 0.50 & 0.46 & 0.81 \\
\hline \multirow{3}{*}{ 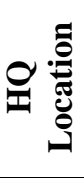 } & Domestic & 0.50 & 0.89 & 1.00 & 0.93 & 0.92 & 0.88 & 0.86 & 0.92 & 0.86 \\
\hline & European_Union & 0.34 & 0.10 & 0.00 & 0.07 & 0.05 & 0.09 & 0.09 & 0.08 & 0.14 \\
\hline & Rest_of_world & 0.16 & 0.01 & 0.00 & 0.00 & 0.03 & 0.03 & 0.05 & 0.00 & 0.00 \\
\hline
\end{tabular}


Table 5: Summary of group characteristics

\begin{tabular}{|c|c|c|c|c|c|c|c|c|c|}
\hline Nuevo & Group 1.1 & Group 2.1 & Group 3.1 & Group 1.3 & Group 2.3 & Group 3.3 & Group 1.2 & Group 2.2 & Group 3.2 \\
\hline & $\mathbf{N}=\mathbf{3 8}$ & $\mathrm{N}=43$ & $\mathbf{N}=\mathbf{2 2}$ & $\mathbf{N}=\mathbf{2 9}$ & $\mathbf{N}=\mathbf{3 4}$ & $\mathbf{N}=\mathbf{2 1}$ & $\mathbf{N}=73$ & $\mathbf{N}=38$ & $\mathbf{N}=\mathbf{2 4}$ \\
\hline \multicolumn{10}{|c|}{ TYPOLOGY OF TECHNOLOGICAL COLLABORATIONS } \\
\hline Object & $\begin{array}{c}\text { Vehicles } \\
\text { (Armament) }\end{array}$ & $\begin{array}{l}\text { Tech_support } \\
\text { VehiclesInputs }\end{array}$ & $\begin{array}{l}\text { Vehicles } \\
\text { (Inputs, } \\
\text { Armament) }\end{array}$ & $\begin{array}{c}\text { Electronics } \\
\text { Communication } \\
\text { (Software) }\end{array}$ & $\begin{array}{c}\text { Electronics } \\
\text { Communication }\end{array}$ & $\begin{array}{c}\text { Electronics } \\
\text { Communication }\end{array}$ & $\begin{array}{l}\text { Communication } \\
\text { (Inputs) }\end{array}$ & \begin{tabular}{|c|} 
Electronics \\
(Communication \\
Armament)
\end{tabular} & $\begin{array}{l}\text { Communication } \\
\text { (Armament) }\end{array}$ \\
\hline Type & $\begin{array}{c}\text { Vertical } \\
\text { Institutional }\end{array}$ & $\begin{array}{l}\text { Consultancy } \\
\text { Institutional }\end{array}$ & $\begin{array}{c}\text { Vertical } \\
\text { Institutional }\end{array}$ & $\begin{array}{c}\text { Only } \\
\text { Consultancy }\end{array}$ & Only vertical & Vertical & Vertical & Only vertical & $\begin{array}{l}\text { Consultancy } \\
\text { Institutional }\end{array}$ \\
\hline International & $50 \%$ & $7 \%$ & $14 \%$ & $0 \%$ & $12 \%$ & $14 \%$ & $11 \%$ & $8 \%$ & $13 \%$ \\
\hline Duration & Very long & Medium & Long & Very Long & Long & Short & Medium & Short & Long \\
\hline $\begin{array}{l}\text { Monthly } \\
\text { investment }\end{array}$ & High & High & Low & High & Medium & High & High & High & Medium \\
\hline $\begin{array}{l}\text { Total } \\
\text { investment }\end{array}$ & Very high & Low & Very low & High & Low & Very Low & Low & Low & Low \\
\hline PROFILE & \multicolumn{3}{|c|}{$\begin{array}{l}\text { MILITARY TECHNOLOGY } \\
\text { COLLABORATION }\end{array}$} & \multicolumn{3}{|c|}{$\begin{array}{l}\text { CIVIL TECHNOLOGY } \\
\text { COLLABORATION }\end{array}$} & \multicolumn{3}{|c|}{$\begin{array}{c}\text { DUAL TECHNOLOGY } \\
\text { COLLABORATION }\end{array}$} \\
\hline \multicolumn{10}{|c|}{ TYPOLOGY OF PARTNERS } \\
\hline Size & Very Large & $\begin{array}{l}\text { Very large } \\
\text { (biggest) }\end{array}$ & Large & Very large & Large & Very large & Very Large & Large (smallest) & Very large \\
\hline Experience & Medium-large & Very Large & $\begin{array}{l}\text { Very Large } \\
\text { (Most } \\
\text { experienced) }\end{array}$ & $\begin{array}{l}\text { Low (Least } \\
\text { experienced) }\end{array}$ & Low & Medium & Low & Medium & Very Large \\
\hline Sector & $\begin{array}{l}\text { Low- Medium } \\
\text { tech }\end{array}$ & Low tech & Low tech & High tech & $\begin{array}{l}\text { Low \& High } \\
\text { tech }\end{array}$ & High tech & Low tech & $\begin{array}{l}\text { Medium-high } \\
\text { tech }\end{array}$ & $\begin{array}{l}\text { Low-Medium } \\
\text { tech }\end{array}$ \\
\hline Group & Group (82\%) & No group (56\%) & $\begin{array}{c}\text { Group/No group } \\
(50 \%)\end{array}$ & Group (97\%) & Group (85\%) & Group (81\%) & Group (95\%) & Group (84\%) & No group (54\%) \\
\hline Location HQ & $\begin{array}{c}\text { Domestic } \\
\text { EU/Rest world }\end{array}$ & Domestic & $\begin{array}{c}\text { Domestic } \\
\text { EU/Rest World }\end{array}$ & Domestic (All) & Domestic & $\begin{array}{l}\text { Domestic } \\
\text { (EU) }\end{array}$ & $\begin{array}{l}\text { Domestic } \\
\text { (EU) }\end{array}$ & Domestic & Domestic \\
\hline
\end{tabular}


Annex: Variables and Measurements

\begin{tabular}{|c|c|c|c|c|c|}
\hline \multicolumn{3}{|c|}{ VARIABLE } & \multicolumn{3}{|c|}{ MEASURE } \\
\hline \multirow{22}{*}{ 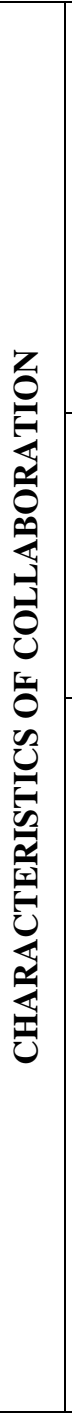 } & \multirow{8}{*}{$\frac{\stackrel{\mathscr{U}}{0}}{\stackrel{0}{0}}$} & Armament & \multirow{8}{*}{$\begin{array}{c}\text { Dummy variable that takes } \\
\text { value } 1 \text { if the object of the } \\
\text { collaboration is ... }\end{array}$} & Armament & \multirow{8}{*}{ and 0 otherwise } \\
\hline & & Electronics & & Electronics & \\
\hline & & Communication & & Communication & \\
\hline & & Software & & Software & \\
\hline & & Inputs & & Inputs & \\
\hline & & Tech_support & & Tech_support & \\
\hline & & Vehicle & & Vehicle & \\
\hline & & Others & & Others & \\
\hline & \multirow{4}{*}{ 芦 } & Vertical & \multirow{4}{*}{$\begin{array}{c}\text { Dummy variable that takes } \\
\text { value } 1 \text { if the collaboration } \\
\text { is with ... }\end{array}$} & Clients & \multirow{4}{*}{ and 0 otherwise } \\
\hline & & Institutional & & $\begin{array}{c}\text { Universities or } \\
\text { Research Centres }\end{array}$ & \\
\hline & & Consultancy & & $\begin{array}{l}\text { Professionals or } \\
\text { consulting }\end{array}$ & \\
\hline & & International & & Foreign partners & \\
\hline & \multirow{10}{*}{ 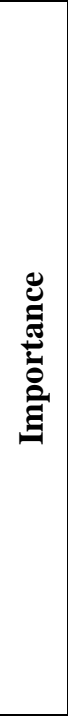 } & Total investment & \multicolumn{3}{|c|}{ It is the amount of total investment in thousands of euros of the collaboration } \\
\hline & & Duration & \multicolumn{3}{|c|}{$\begin{array}{l}\text { It is calculated as the difference between end and start date (in months) of } \\
\text { the collaboration }\end{array}$} \\
\hline & & Short & \multirow{3}{*}{$\begin{array}{c}\text { Dummy variable that takes } \\
\text { value } 1 \text { for collaborations } \\
\text { with duration... }\end{array}$} & up to 1 year & \multirow{3}{*}{ and 0 otherwise } \\
\hline & & Medium & & $\begin{array}{l}\text { more than } 1 \text { and up to } \\
2 \text { years }\end{array}$ & \\
\hline & & Long & & more than 2 years & \\
\hline & & \begin{tabular}{|l|l} 
Monthly \\
Investment
\end{tabular} & \multicolumn{3}{|c|}{$\begin{array}{l}\text { It is the amount of total investment divided by the duration of the } \\
\text { collaboration in thousands of euros }\end{array}$} \\
\hline & & Low & \multirow{4}{*}{$\begin{array}{c}\text { Dummy variable that takes } \\
\text { value } 1 \text { for collaborations } \\
\text { with a monthly } \\
\text { investment... }\end{array}$} & less than $€ 10,000$ & \multirow{4}{*}{ and 0 otherwise } \\
\hline & & Medium & & $\begin{array}{l}\text { from } € 10,000 \text { to } \\
€ 50,000\end{array}$ & \\
\hline & & High & & $\begin{array}{l}\text { from } € 50,000 \text { to } \\
€ 500,000\end{array}$ & \\
\hline & & Very high & & more than $€ 500,000$ & \\
\hline \multirow{9}{*}{ 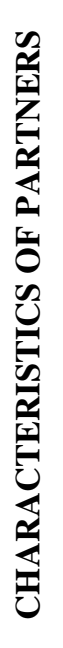 } & \multicolumn{2}{|c|}{ Size } & \multicolumn{3}{|c|}{ Number of employees } \\
\hline & \multicolumn{2}{|c|}{ Experience } & \multicolumn{3}{|c|}{ Number of years since the foundation of the firm } \\
\hline & \multicolumn{2}{|c|}{ Group } & \multicolumn{3}{|c|}{$\begin{array}{l}\text { Dummy variable that takes value } 1 \text { when the firm belongs to an industrial } \\
\text { group and } 0 \text { otherwise }\end{array}$} \\
\hline & \multirow{3}{*}{ 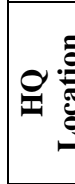 } & Domestic & \multirow{3}{*}{$\begin{array}{c}\text { Dummy variable that takes } \\
\text { value } 1 \text { when the partner is } \\
\text { from... }\end{array}$} & Spain (domestic) & \multirow{3}{*}{ and 0 otherwise } \\
\hline & & European_Union & & European Union & \\
\hline & & Rest_of_world & & Rest of the world & \\
\hline & \multirow{3}{*}{ לัँّ้ } & High_tech & & $\begin{array}{l}\text { High technological } \\
\text { sector }\end{array}$ & \\
\hline & & Medium_tech & $\begin{array}{l}\text { Dummy variable that takes } \\
\text { value } 1 \text { when the firm }\end{array}$ & \begin{tabular}{|c|}
$\begin{array}{c}\text { Medium technological } \\
\text { sector }\end{array}$ \\
\end{tabular} & and 0 otherwise \\
\hline & & Low_tech & & $\begin{array}{l}\text { Low technological } \\
\text { sector }\end{array}$ & \\
\hline
\end{tabular}

